\title{
First faunistic results on Valencia (Cresques) Seamount, with some ecological considerations
}

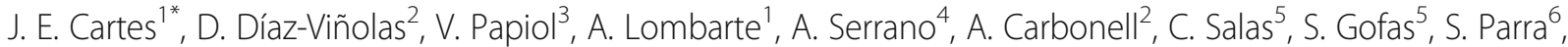 \\ D. Palomino ${ }^{7}$ and D. Lloris ${ }^{1}$
}

\begin{abstract}
The living and dead fauna of Valencia Seamount, a deep promontory in the middle of the Balearic Basin which summit is at ca. $1100 \mathrm{~m}$ depth, is described by first time based in a rock dredge perfomed in a sedimentary area of the summit Mount. Surface-feeder polychaetes (the Paraonidae Levinsenia gracilis and Terebellidae as dominant), and taxodont bivalves (Ledella messanensis and Yoldiella ovulum) were the main species of benthos. We found alive remains of the bamboo coral Isidella elongata, a vulnerable, habitat-forming species in the deep Mediterranean. Benthos density was low (0.6 organisms $/ 2 \mathrm{dm}^{3}$ mud). Thanatocoenosis evidenced a rather moderate diversity of benthic bivalves (11 species) and gastropods ( 9 species) also dominated by surface deposit feeders. Fish (identified/ quantified from sedimented otoliths) showed diversified and abundant mesopelagic fauna, mainly Myctophidae. More interestingly, we highlighted among benthopelagic fish the occurrence of recruits of Merluccius merluccius, Micromesistius poutassou, or Hymenocephalus italicus, all species that live in the neighboring slopes of the Iberian Peninsula and the Balearic Islands at quite shallower depths (at 100-700 m) than their distribution in the Valencia Seamount summit (1102-1130 m) based on the deposited otoliths found. Some ecological aspects were discussed and the necessity to consider the deep Valencia Seamount as a potential area that should be under protection.
\end{abstract}

\section{Introduction}

According to Barone and Ryan (1987), the Valencia Seamount is an elongated mount located in the Balearic Basin (western Mediterranean), oriented NW-SE, with numerous spurs whose shape resembles a short-legged insect or starfish. It is located close $(7-8.5 \mathrm{~km})$ to the Valencia Trough, where we found maximal depths of $2200-2300 \mathrm{~m}$ in the Balearic Basin. In 1986, these authors described the morphology of this mount using side-looking sonar (Sea MARC I) and swath-mapping sonar (Sea Beam), which yielded detailed bathymetric and sedimentary maps. More recently, this submarine structure was named the Cresques Seamount (Rovere and Würtz 2015) in honour of a recognized Balearic

\footnotetext{
* Correspondence: jcartes@icm.csic.es

${ }^{1}$ Institut de Ciències del Mar (ICM-CSIC), Passeig Marítim de la Barceloneta,

27-49, 08003 Barcelona, Catalonia, Spain

Full list of author information is available at the end of the article
}

cartographer. The Valencia seamount summit lies 1020 $\mathrm{m}$ below sea level, emerging from depths of ca. $1900 \mathrm{~m}$. There are different "peaks" in the upper part of the mount. By echo sounding, in 2010 (ANTROMARE cruise), we found summits at $1067 \mathrm{~m}$. Traditionally, the geological definition of a seamount considers that mount summits rise more than $1000 \mathrm{~m}$ above the surrounding seafloor, while the Valencia seamount height is close to $900 \mathrm{~m}$. This seems to be, however, a general definition that does not consider the particularities of each area. In the case of the western Mediterranean, the greatest depths recorded hardly reach $3500 \mathrm{~m}$.

The Valencia Seamount likely emerged during the Messinian Desiccation. It features volcanic rocks, and in its summit and the upper parts of the slopes (ca. 1020-1300 m), there are avalanche scars and debris flow deposits with sedimentary bottoms (Barone and Ryan 1987).

(c) The Author(s). 2021 Open Access This article is licensed under a Creative Commons Attribution 4.0 International License, which permits use, sharing, adaptation, distribution and reproduction in any medium or format, as long as you give appropriate credit to the original author(s) and the source, provide a link to the Creative Commons licence, and indicate if changes were made. The images or other third party material in this article are included in the article's Creative Commons licence, unless indicated otherwise in a credit line to the material. If material is not included in the article's Creative Commons licence and your intended use is not permitted by statutory regulation or exceeds the permitted use, you will need to obtain permission directly from the copyright holder. To view a copy of this licence, visit http://creativecommons.org/licenses/by/4.0/. 
The Valencia Seamount should be classified according to Porteiro and Sutton (2007) as a deep seamount, the summit of which is influenced by bathypelagic (low-nonmigratory) fauna and no longer by mesopelagic (daily migrant) fauna. However, detailed trophic studies performed in the Balearic Basin (Cartes 1998) indicated that the influence of mesopelagic euphausiids (Meganyctiphanes norvegica) or decapods (Sergestes arcticus) in the diets of demersal fish and decapods may reach $1200-1300 \mathrm{~m}$, which would include the summit of the Valencia seamount.

From 1985 to the current date (2020), intense faunistic and ecological studies have been conducted in the Balearic Basin, with transects performed between the coasts of Catalonia and the North of Mallorca, covering regular depth intervals - each 100-200 m - to depths between 200 and $2300 \mathrm{~m}$ in the Balearic Basin (Cartes et al. 2015 and references cited; see also Fig. 1). Fish and large invertebrate communities, trophic relationships, zooplankton, suprabenthos and, generally speaking, the ecology and function of these ecosystems have been analysed in projects focused on deep sea ecology, from BATIMAR (1987-1989) to RECOMARES (2020), the last of which focused on the reconstruction of deep communities. Due to its inaccessibility, the fauna living over the Valencia (Cresques) Seamount was not sampled; thus, its composition is practically unknown, except for some zooplankton samples taken from its summit (Cartes et al. 2013). Even other indirect information available is anecdotal, with the fishery sites available on the web naming the Cresques Knoll as a hotspot for recreational fishing (https://fishingstatus.com/2. In this way, it is documented that tunnid fishing occurs over some seamounts (Holland et al. 1999).

The objective of this study is to describe the fauna of the Valencia seamount for the first time, based on both its living animals and reconstructions of fauna from the thanatocoenosis, i.e., the remains filtered from the sediment. We also intent to awaken interest in the study of an area that should be considered a conservation area due to the presence of different habitats and species of community interest that must inhabit the Valencia seamount. Intense faunistic studies performed in areas surrounding the Valencia seamount, both over the mainland (Catalonia) and in the insular (Balearic Islands) slopes of the Balearic Basin, will allow comparisons of fauna dwelling in and surrounding this special environment and will demonstrate the particularities of the communities associated with this seamount.

\section{Methods}

In the framework of the cruise RECOMARES0320 (2-14 March 2020), we performed sampling over Valencia Seamount bottoms at $40^{\circ} 25.469 \mathrm{~N}-2^{\circ} 43.11 \mathrm{E}(11 / 03 /$ 2020) at depths of 1102-1130 m (Fig. 1), using a Rock Dredge, with a mouth $80 \times 30 \mathrm{~cm}$ in size and an $8-\mathrm{mm}$

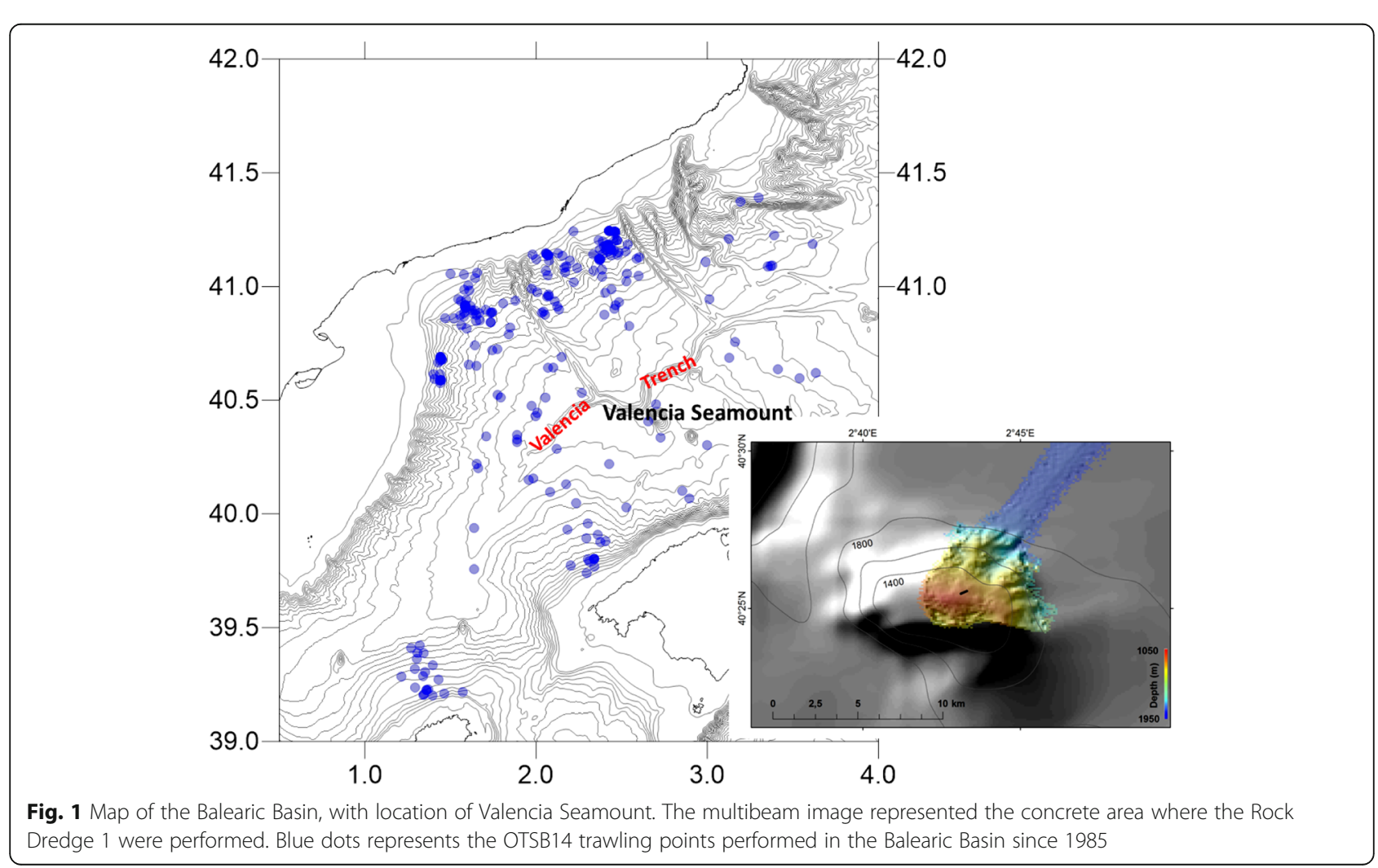


mesh size at the cod-end. We were searching for proper depths to perform a multicore sampling for the reconstruction of past communities in an area that has been historically free of trawling activity, and thus would have unaltered bottoms. We performed a single sampling (DR1) of ca. $10 \mathrm{~min}$, trawling the dredge at $1 \mathrm{knot}$, covering $0.015 \mathrm{ha}$ and $279.3 \mathrm{~m}$. The sampling was performed by the R/V García del Cid (length $37.2 \mathrm{~m}$ ).

A high volume of sediment (sandy mud, without any rock or large stones) was collected, and approx. $60 \mathrm{~L}$ of mud was filtered through $0.5-\mathrm{mm}$ sieves. The depth of the sediment sampled must be $20-30 \mathrm{~cm}$, i.e., the maximum height of the dredge mouth.

A total of $832 \mathrm{~g}$ of filtered debris was obtained and sorted under a stereomicroscope at $\times 10-\times 20$ magnification. We searched for both living and dead remains of fauna, i.e., the last to reconstruct the communities of these soft depths of the Seamount. Living fauna were counted and identified to the lowest possible taxonomic level. Thanatofauna were also counted, and pteropods were quantified by extrapolating numbers to aliquots of sediment analysed. For fish (quantified from non- or hardly broken otoliths), the results were given in ranges between 10 and 50,50-100, 100-900 and >900 specimens since otoliths were very abundant.
Bathymetry data were obtained over the concrete area where Rock Dredge 1 was performed using an Elac Seabeam 1050D multibeam echo sounder installed in the hull of the R/V García del Cid. Data were processed with the CARIS HIPS \& SIPS programme, generating a bathymetric model of 100-m resolution.

\section{Results}

Living fauna were scarce (Table 1), represented mainly by polychaetes as the most abundant taxa, with 4 species (Paraonidae Levinsenia gracilis and Terebellidae as dominant). Bivalves belonged to Nuculanida (Taxodonta), with two species (Ledella messanensis and Yoldiella ovulum). Other taxa (Sipuncula, Nematoda and Enteropneusta) were represented by single specimens. Among sessile epibenthos, a number of settled phases of medusae (Stephanoscyphus spp.) fixed on shells and other debris were counted. We also found living remains of the bamboo coral Isidella elongata, consisting of 3 branch pieces with 5 polyps, plus fresh sclerites. No bases were collected, and these remains probably belonged to colonies distributed in areas in close proximity to the Valencia Seamount, which may be less sedimentary. Two elements of suprabenthos were collected: 1 siphonophore (Chelophyes appendiculata) and 1 Cirolanid isopod (Eurydice truncata).

Table 1 List of alive fauna found in Valencia Seamount (Rock Dredge 1)

\begin{tabular}{|c|c|c|}
\hline \multicolumn{3}{|c|}{ Faunistic List of species in Valencia Seamount } \\
\hline \multicolumn{3}{|l|}{ DR 1} \\
\hline \multicolumn{3}{|l|}{ Living Fauna } \\
\hline \multicolumn{3}{|l|}{ Cnidaria } \\
\hline Chelophyes appendiculata & 1 & \\
\hline Isidella elongata & 1 & Remains of alive colony ( 5 polyps) \\
\hline Stephanoscyphus spp. & 6 & \\
\hline \multicolumn{3}{|l|}{ Polychaeta } \\
\hline Levinsenia gracilis (Paraonidae) & 4 & \\
\hline Spionidae ( Prionospio sp.) & 2 & \\
\hline Onuphidae (Paradiopatra sp.) & 1 & \\
\hline Terebellidae & 5 & \\
\hline Sipuncula & 1 & \\
\hline Enteropneusta & 1 & \\
\hline Nematoda & 1 & \\
\hline \multicolumn{3}{|l|}{ Crustacea Isopoda } \\
\hline Eurydice truncata & 1 & \\
\hline \multicolumn{3}{|l|}{ Bivalvia } \\
\hline Ledella messanensis & 3 & \\
\hline Yoldiella ovulum & 1 & \\
\hline
\end{tabular}


The dredge used can be considered a semiquantitative sampler, and the density of benthos in the Valencia Seamount was 0.6 organisms $/ 2 \mathrm{dm}^{3}$ mud. The mud mainly consisted of pelagic debris, mainly foraminiferans tecae (Orbulina universa and Globigerinidae). The \% of organic content (by difference from dry weight, after combustion for $4 \mathrm{~h}$ at $450{ }^{\circ} \mathrm{C}$ ) was $6.44 \pm 0.19$.

Thanatofauna (Table 2) was represented by benthic bivalves (11 species) and gastropods (9 species). Taxodont species were dominant. Fish were identified/quantified from sedimented otoliths, and 27 species were identified. The most diversified and abundant were Myctophidae and other mesopelagic species. Among benthopelagic-benthic species, we highlight the occurrence of small specimens of species (Merluccius merluccius, Micromesistius poutassou, Hymenocephalus italicus) that live in the neighbouring slopes of the Iberian Peninsula and the Balearic Islands at fairly shallower depths (between 100 and $700 \mathrm{~m}$ ) that were sampled from the Valencia Seamount summit (1102-1130 m).

\section{Discussion}

Due to its rugged morphology, the bottoms of the Valencia Seamount (VS) have been inaccessible to date. Regarding its fauna, the area is considered unexplored. Its eventual protection has not been considered to date, despite the different initiatives to protect diverse and vulnerable habitats in open seas in recent years. The summit of the VS, at ca. $1100 \mathrm{~m}$, is as far as $50-90 \mathrm{~km}$ from comparable depths in the neighbouring Iberian Peninsula and the Balearic Islands (Mallorca Island) in the Balearic Basin. The first results obtained from a single (DR1) dredge indicated that the VS can be populated by vulnerable, habitat-forming species, i.e., the bamboo coral Isidella elongata. Additionally, regarding the list of living species and thanatofauna, the VS showed nonnegligible diversity. According to Porteiro and Sutton's (2007) classification, it is also a good example of a deep seamount with a summit that is influenced by bathypelagic (lownonmigratory) fauna. The muddy depths of the VS also seem adequate to harbour populations of commercial species such as the red shrimp Aristeus antennatus, free of any trawling pressure. Aristeus antennatus is the main target species in deep fisheries in the Balearic Basin and is widely distributed at $2300 \mathrm{~m}$ throughout the basin (Cartes et al. 2018). The situation would be similar to that recently evidenced over Galicia Bank, which acts as a possible reservoir for exploited shrimps (Cartes et al. 2020).

The dredge used was a semiquantitative sampler and yielded a low density of benthos in Valencia Seamount sediments $\left(0.6\right.$ organisms $/ 2 \mathrm{dm}^{3}$ ) compared with some older studies using similar devices performed off Monaco and Corse (2.9, 8.0 or 11.5 organisms (macrofauna) $/ 2 \mathrm{dm}^{3}$, Carpine 1970) at comparable slope depths (300-1200 m).
Table 2 Thanatofauna in Valencia Seamount muds (Dredge 1): (+) 10-50 specimens counted; (++) 50-100 speciemens; (+++) 100-900 speciemns; $++++>900$ specimens. ${ }^{1}$ Damaged

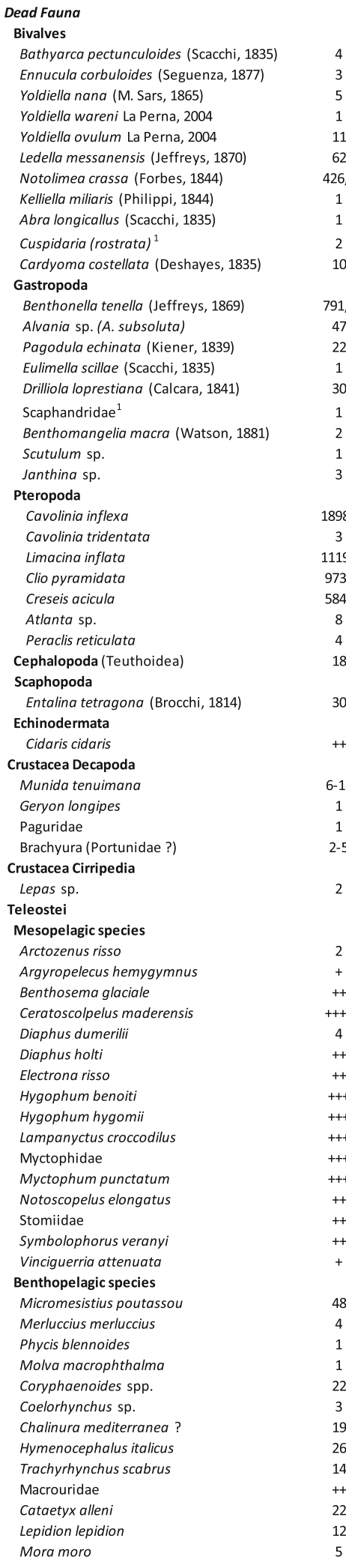


In addition, the dominant trophic guild of the main species identified was surface deposit feeders, both among bivalves (mainly Taxodonta) and, according to Fauchald and Jumars (1979), identified polychaetes (e.g., the Paraonidae Levinsenia gracilis). This result is consistent with a rather low \%OM of sediments (6.4\%) compared to the percentages of $8-12 \%$ found in mainland bathyal sediments (Carpine 1970).

The remainder of mesopelagic species were dominant on the VS sediments, including foraminiferans, pteropods and mesopelagic Myctophids. This is not surprising considering the oceanic, i.e., isolated from the mainland, characteristics of the area. The most abundant lanternfish was Ceratoscopelus maderensis, as found for living fauna in some macroplankton samples taken over the VS (Cartes et al. 2013). Additionally, we found that species of Hygophum spp. or Diaphus spp. were more abundant over the insular part of the Balearic Basin, and not on the central Catalan coast, author's unpublished RECOMARES data). The most curious aspect, however, was found for benthic/demersal fish since species, such as Micromessistius poutassou and Hymenocephalus italicus, were relatively abundant. These fish never/hardly reached $700-900 \mathrm{~m}$ deep in the adjacent slopes of the Catalonia-Balearic Islands, located (at comparable depths) $50-90 \mathrm{~km}$ from the summit of the Valencia Seamount. In fact, the composition of the most abundant fish collected over the VS was quite different from the species found on both sides of the Balearic Basin at comparable depths (1050-1200 m, Fig. 2). Over the VS, dominant species such as Alepocephalus rostratus and Bathypterois mediterraneus were absent among the sedimented otoliths recorded. In addition, otoliths always belonged to small specimens; for example, those of $M$. poutassou or hake were $6-8 \mathrm{~cm}$ TL (juveniles) that live at depths as shallow as $100-400 \mathrm{~m}$ in the shelf or the shelf-slope break, according to the smaller shallower trends of such species in the western Mediterranean (Stefanescu et al. 1992; Morales-Nin et al. 2003).
Assuming that this thanatofauna is representative of the living fauna over the VS summit, at the top of Valencia Seamount, we would find species clearly distributed at lower depths in adjacent slopes of the middle-upper slope composed of recruits with, among the fish dwelling at these depths, a quite different trophic structure rather than that dominated by epibenthos feeders. Such comparisons must be made with caution due to the limitations of this first single sampling event, and further studies to determine the living fauna of this deep seamount are necessary to verify its local importance as a recruitment/reservoir area for shallow water fish and shrimp. This would help to discard other explanations, e.g., that otoliths reached the top of the promontory by resuspension in nepheloid layers, which seems unlikely because adjacent slopes are far from the VS.

\section{Conclusion}

Despite the preliminary nature of the data, living dominant macrofauna over the summit $(1102-1130 \mathrm{~m})$ of the Valencia seamount, an isolated deep seamount (summit ca. $1100 \mathrm{~m}$ ) in the middle of the Balearic Basin, were rather poor and consisted of surface deposit feeder polychaetes and bivalves. Remains of the bamboo coral Isidella elongata, a vulnerable habitat-forming species, also occurred on the seamount. Among thanatofauna, benthic bivalves and gastropods were quite diversified. A number of fish (identified by sedimented otoliths) occurred as small recruits, with species (Merluccius merluccius, Micromesistius poutassou, or Hymenocephalus italicus) that live in the neighbouring mainland/insular slopes at shallower depths (at 100-700 m). These findings suggest that the Valencia Seamount summit could act as a recruitment area for shallow-water species. Since the area has been free of impacts such as trawling, the Valencia Seamount provides an optimal study area to evaluate natural changes via deep-sea ecosystems studies focused on the reconstruction of past communities, such as those by the RECOMARES project.

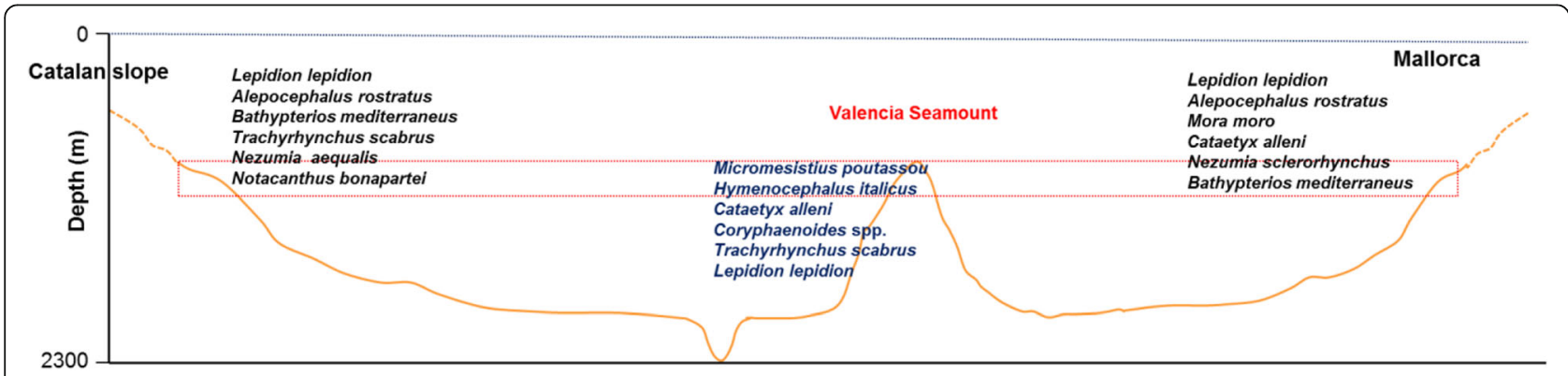

Fig. 2 Scheme of the Balearic Basin profile. The composition of main benthopelagic teleosteans was included (by decreasing rank of abundance) in both sides (Catalonia and Mallorca) of the basin, and in the summit of Valencia Seamount (current data, Table 1). Composition of Catalan and Mallorca slopes is based on alive fauna collected by trawling (OTSB14) performed in the last 3 decades (1985-2020) 


\section{Abbreviation}

VS: Valencia Seamount

\section{Supplementary information}

The online version contains supplementary material available at https://doi. org/10.1186/s41200-021-00210-y.

\section{Additional file 1 .}

\section{Acknowledgements}

The study was financed by the MICYT project RECOMARES (RTI2018-094066B-I00) funded by Ministerio de Ciencia e Innovación, MICYIT. The authors thank all members of the crew of the RN García del Cid. We acknowledge support of the publication fee by the CSIC Open Access Publication Support Initiative through its Unit of Information Resources for Research (URICI).

\section{Authors' contributions}

The first 6 authors participated in the sampling (cruise), together with D. Lloris. Practically all authors contributed in the classification of organisms listed, Cartes, Papiol and Carbonell revised crustaceans and pteropods, DíazViñolas cnidarians, Lombarte and Lloris fishes, especially otoliths, Serrano, Salas and Gofas benthic mollusks, Parra polychaetes. Palomino worked on the multibeam data to generate image in Fig. 1. All them contributed in the discussion, e.g. documenting trophic guilds in the respective taxa. Cartes wrotte the version of the text. The author(s) read and approved the final manuscript.

\section{Funding}

Funding organims are in acknowledgements, CSIC is assuming part of the cost to pay open access taxes in the case of acceptance.

Availability of data and materials

Possible, always with authors'permission and supervision.

\section{Declarations}

Ethics approval and the consent to participate

All authors were informed and agreed with this initiative.

\section{Consent for publication}

Not applicable.

\section{Competing interests}

No potential conflict of interest reported by the authors.

\section{Author details}

${ }^{1}$ Institut de Ciències del Mar (ICM-CSIC), Passeig Marítim de la Barceloneta, 27-49, 08003 Barcelona, Catalonia, Spain. ${ }^{2}$ Instituto Español de Oceanografía, Centro Oceanográfico de Baleares, E-07015 Palma de Mallorca, Islas Baleares, Spain. ${ }^{3}$ Escuela Nacional de Estudios Superiores Unidad Mérida, Universidad Nacional Autónoma de México, Calle 7B \#227 ×20 y 22, Fco. de Montejo, Mérida, Yucatán, Mexico. ${ }^{4}$ Centro Oceanográfico de Santander, Instituto Español de Oceanografía, Promontorio San Martín de Bajamar, s/n, 39004 Santander, Cantabria, Spain. ${ }^{5}$ Departamento de Biología Animal, Facultad de Ciencias, Universidad de Málaga, Campus de Teatinos, E-29071 Málaga, Spain. ${ }^{6}$ IEO - Centro Oceanográfico A Coruña, Paseo Marítimo Alcalde Francisco Vázquez, n¹0, 15001 A Coruña, Spain. ${ }^{7}$ IEO - Centro Oceanográfico de Málaga, Centro Oceanográfico de Málaga, Puerto Pesquero s/n, 29640 Fuengirola (Málaga), Spain

Received: 8 February 2021 Accepted: 1 July 2021

Published online: 07 September 2021

\section{References}

Barone AM, Ryan WBF. Morphology from subaerial erosion of a Mediterranean seamount. Mar Geol. 1987;74(3-4):159-72. https://doi.org/10.1016/0025-322 7(87)90048-X

Carpine C. Ecologie de l'étage bathyal dans la Méditerranée occidentale. Mémoires I'Institut Océanographique Monaco. 1970;2:146.
Cartes JE. Feeding strategies and partition of food resources in deep-water decapod crustaceans (400-2300 m). J Mar Biol Assoc U K. 1998;78(2):509-24. https://doi.org/10.1017/S002531540004159X.

Cartes JE, Fanelli E, López-Pérez C, Lebrato M. Deep-sea macroplankton distribution (at 400 to $2300 \mathrm{~m}$ ) in the northwestern Mediterranean in relation to environmental factors. J Mar Syst. 2013;113-114:75-87. https://doi.org/10.1 016/j.jmarsys.2012.12.012.

Cartes JE, López-Pérez C, Carbonell A. Condition and recruitment of Aristeus antennatus at great depths (to $2300 \mathrm{~m}$ ) in the Mediterranean: relationship with environmental factors. Fish Oceanogr. 2018;27(2):114-26. https://doi. org/10.1111/fog.12237.

Cartes JE, Maynou F, Fanelli E, López-Pérez C, Papiol V. Changes in deep-sea fish and crustacean communities at 1000-2200m in the Western Mediterranean after 25 years: relation to hydro-climatic conditions. J Mar Syst. 2015;143:13853. https://doi.org/10.1016/j.jmarsys.2014.10.015.

Cartes JE, Rodríguez-Ribas R, Papiol V, Valeiras X, Punzón A, Blanco M, et al. Biological condition and population structure of benthopelagic shrimps in the Galicia Bank (NE Atlantic): intra- and interspecific patterns. Deep Sea Res. 2020;168:103434. https://doi.org/10.1016/j.dsr.2020.103434.

Fauchald K, Jumars PA. The diet of worms: a study of polychaete feeding guilds. Oceanogr Mar Biol Annu Rev. 1979;17:193-284.

Holland KN, Kleiber P, Kajiura SM. Different residence times of yellowfin tuna, Thunnus albacares, and bigeye tuna, T. obesus, found in mixed aggregations over a seamount. Fish Bull. 1999;97:392-5.

Morales-Nin B, Sardá F, Maynou F, Cartes JE, Moranta J, Massutí E, et al. Size influence and zonation patterns in fishes and crustaceans from the deep water communities of the Western Mediterranean. J NAFO. 2003;31:401-13.

Porteiro F, Sutton TT. Midwater Fish Assemblages and Seamounts. In: Pitcher TJ, Morato T, Hart PJB, Clark MR, Haggan N, Santos RS, editors. Seamounts: ecology, Fisheries \& Conservation: Wiley; 2007. p. 101-6.

Rovere $M$, Würtz M. Atlas of the Mediterranean seamounts and seamountlike structures, Fondation MAVA pour la nature, IUCN, global marine and polar Programme, IUCN Centre for Mediterranean Cooperation. Málaga: IUCN; 2015.

Stefanescu C, Rucabado J, Lloris D. Depth-size trends in western Mediterranean demersal deep-sea fishes. Marine Ecol Prog Ser. 1992;81:205-13.

\section{Publisher's Note}

Springer Nature remains neutral with regard to jurisdictional claims in published maps and institutional affiliations.

Ready to submit your research? Choose BMC and benefit from:

- fast, convenient online submission

- thorough peer review by experienced researchers in your field

- rapid publication on acceptance

- support for research data, including large and complex data types

- gold Open Access which fosters wider collaboration and increased citations

- maximum visibility for your research: over $100 \mathrm{M}$ website views per year

At $\mathrm{BMC}$, research is always in progress.

Learn more biomedcentral.com/submissions 